\title{
Seduhan Bubuk Kopi Robusta Spray Dryed Meningkatkan Viabilitas Monosit yang Dipapar Eksotoksin Streptococcus mutans (In Vitro)
}

(Spray Dryed Robusta Coffee Brew Increase the Viability of Monocytes Exposed by Streptococcus mutans Exotoxins In Vitro)

Fiftiani Syarah ${ }^{*}$, I Dewa Ayu Susilawati², Nadie Fatimatuzzahro²

1* Fakultas Kedokteran Gigi, Universitas Jember, Indonesia

2 Bagian Biomedik, Fakultas Kedokteran Gigi, Universitas Jember, Indonesia

\section{Abstrak}

Respon pertahanan monosit melawan eksotoksin bakteri dapat menyebabkan kerusakan sel, karena produksi senyawa antimikroba seperti oksidan dan radikal bebas. Seduhan kopi robusta spray dryed mengandung antioksidan yang diduga dapat menangkap oksidan dan radikal bebas yang dapat mengarah pada pencegahan kerusakan sel. Penelitian ini bertujuan untuk membuktikan efek seduhan kopi robusta spray dryed (SDCRB) terhadap peningkatan viabilitas monosit setelah dipapar eksotoksin S.mutans (in vitro). Jenis penelitian ini adalah penelitian eksperimental dengan post test only controle group design. Obyek penelitian ini adalah monosit dari darah perifer manusia, yang diisolasi dengan metode gradient centrifugation. Viabilitas monosit dianalisis menggunakan pewarnaan trypan blue. Parameter dari penelitian ini adalah persentase viabilitas monosit. Data dianalis menggunakan Anova dan LSD. Monosit yang diinkubasi dengan SDRCB menunjukkan signifikasi $(p<05)$ viabilitas lebih tinggi (96.95\%) daripada monosit tanpa SDRCB $(94,27 \%)$. Seduhan kopi robusta spray dryed dapat meningkatkan viabilitas monosit yang dipapar S.mutans (in vitro).

Kata Kunci: antioksidan, kerusakan sel, radikal bebas, uji trypan blue

\section{Abstract}

Monocytes response against bacterial exotoxins can cause cell damage, due to the production of antimicrobial compounds such as oxidants and free radicals. Spray dryed robusta coffee brewed contained antioxidants that was alleged to be able counteract oxidants and free radicals leading to prevent cell damage. This research aimed to prove the effect of spray dryed robusta coffee brew (SDRCB) to increase monocytes viability after being exposed by exotoxins of Streptococcus mutans (in vitro). This in vitro experimental study used the post test only control group design. The object of study was human peripheral blood monocytes, isolated by means of gradient centrifugation method. Monocyte viability was analyzed by trypan blue assay. The parameter was the percentage viable monocytes. Data were analyzed using Anova and LSD. Monocytes incubated with SDRCB showed a significant $(p<05)$ higher viability (96.95\%) than monocytes without SDRCB (94,27\%). Spray dryed robusta coffee brew proved to be able increase viability of monocytes after S.mutans exposure (in vitro).

Keywords: Antioxidant; cell damage;Free radicals;Ttrypan blue assay.

Korespondensi (correspondence) : Fiftiani Syarah Jalan Kalimantan 37, Jember 68121 fiftianisyarah@yahoo.com

Monosit yang viabel (memiliki membran sel yang utuh) merupakan salah satu komponen penting pertahanan tubuh dalam melawan melawan infeksi mikroorganisme. Monosit sebagai sel fagositik berfungsi mengenali, menangkap dan menghancurkan antigen. Salah satu mekanisme respon pertahanan monosit adalah menggunakan oxidan dan radikal bebas (Reactive Oxygen Spesies, ROS) untuk melawan antigen. 1,2,3

Reactive Oxygen Spesies dalam konsentrasi rendah hingga sedang dibutuhkan dalam proses fisiologis, namun pada kondisi berlebih ROS dapat menyebabkan terjadinya stres oksidatif yang akan mengakibatkan kerusakan struktur sel.2,4 ROS menyebabkan peroksidasi lipid pada ikatan lemak membran sel, kerusakan DNA inti sel, dan kerusakan protein. ${ }^{4}$ Kerusakan struktur membran akibat peroksidasi lipid berefek secara langsung terhadap fluiditas, struktur dan fungsi membran sel yang akan mengakibatkan menurunnya kemampuan sel untuk mempertahankan hidup, tumbuh dan berkembang (viabilitas).
Sel yang tidak dapat mempertahankan hidupnya akan mengakibatkan kematian sel.5,6 Kerusakan sel akibat ROS dapat berhenti apabila reaktivitasnya diredam oleh senyawa yang bersifat antioksidan. ${ }^{4}$

Antioksidan berfungsi mencegah atau menunda oksidasi dengan mendonorkan satu elektronnya kepada radikal bebas sehingga menghentikan chain reaction. ${ }^{2,7}$ Antioksidan secara alami bisa didapatkan dari kopi. Antioksidan yang terkandung dalam kopi merupakan yang paling tinggi bila dibandingkan dengan teh, coklat dan wine dalam sekali seduh. ${ }^{8}$ Kopi memiliki berbagai macam jenis, salah satunya adalah kopi robusta. Kopi robusta diketahui memiliki kandungan antioksidan yang lebih tinggi daripada kopi arabika. ${ }^{9}$ Senyawa antioksidan yang terkandung dalam kopi robusta antara lain asam klorogenat (polifenol), kafein dan alkaloid.9,10

Sediaan kopi yang siap dikonsumsi, sebelumnya harus melalui berbagai proses pengolahan. Hal ini diduga dapat 
berpengaruh terhadap ketersediaan antioksidan dalam sediaan kopi." Salah satu metode pengolahan kopi adalah dengan spray dryed. Metode Spray dryed dilakukan dengan menyemprot ekstrak kopi menggunakan suhu tinggi dan mengeringkan ekstrak tersebut sehingga menjadi bubuk kopi instan. Proses pengolahan kopi secara spray dryed diduga dapat meningkatkan kadar antioksidan. 8,12,13

Kadar antioksidan yang tinggi dalam kopi instan spray dryed diduga dapat dimanfaatkan untuk meningkatkan viabilitas sel-sel pertahanan tubuh untuk melawan agen infeksius, misalnya eksotoksin S. mutans (bakteri utama penyebab karies gigi). Berdasarkan uraian tersebut penelitian bertujuan menganalisis efek seduhan kopi robusta spray dryed terhadap viabilitas monosit yang dipapar eksotoksin S. mutans secara in vitro.

\section{METODE PENELITIAN}

Penelitian ini merupakan experiment laboratories (in vitro) dengan rancangan penelitian the post test only control group design. Perlakuan dalam penelitian ini adalah paparan (inkubasi) seduhan bubuk kopi spray drying terhadap monosit yang dipapar eksotoksin S. mutans. Penelitian ini terbagi menjadi 3 kelompok yaitu 1) kelompok kontrol (K) yakni isolat monosit dipapar oleh eksotoksin S. mutans, 2) kelompok kopi spray drying (KS) dimana isolat monosit dipapar oleh kopi spray drying dan eksotoksin S. mutans, dan 3) kelompok kopi bubuk biasa (KB) yaitu isolat monosit dipapar oleh kopi bubuk biasa dan eksotoksin S. mutans.

Bahan untuk isolasi monosit meliputi lymphoprep (Polymophprep TM), tabung heparin (Vacutube), bubuk kopi robusta murni (Gunung ljen, PTPN XII), bubuk kopi spray dryed (bubuk kopi murni yang diolah secara spray drying). Eksotoksin S. mutans (Isolat dari F.MIPA Universitas Jember) disaring menggunakan syringe filter (Minisart 0,2um). Isolat monosit yang diisolasi dari darah vena peripheral. Ethical clearance disetujui oleh Komisi Etik Fakultas Kedokteran Gigi Universitas Jember (Nomer 112/UN25.8/KEPK/DL/2018)

Pembuatan bubuk kopi dilakukan di Laboratorium RPHP Fakultas Teknologi Pertanian Universitas Jember. Bubuk kopi robusta sebanyak 500 gram di ekstraksi menggunakan air mendidih perbandingan kopi dan air 1:2, kemudian disaring menggunakan ayakan mess 100. Hasil penyaringan dilakukan penyemprotan pada suhu $140^{\circ} \mathrm{C}$ sehingga air akan menguap dan filtrat akan jatuh ke tabung menjadi kopi bubuk instan.

Monosit diisolasi menggunakan metode gradient sentrifugasi. Tahap pertama mengambil sampel darah pada subyek penelitian sebanyak $6 \mathrm{ml}$ dan dimasukkan kedalam tabung heparin. Memasukkan sampel darah kedalam tabung falcon yang telah terisi dengan lymphoprep dengan perbandingan darah dengan lymphoprep 2:1 . Sampel darah dilakukan sentrifugasi dengan kecepatan $2100 \mathrm{rpm}$ selama 30 menit pada suhu $27^{\circ} \mathrm{C}$. Mengambil lapisan mononuclear dan mengencerkan menggunakan RPMI dan dihomogenkan. Mononuklear dilakukan sentrifugasi dengan kecepatan $1800 \mathrm{rpm}$ selama 15 menit pada suhu $20^{\circ} \mathrm{C}$. Hasil isolasi diteteskan kedalam coverslip pada well plate culture 24 sebanyak $100 \mu \mathrm{l}$ dan dilakukan prosedur penempelan sel di inkubator selama 30 menit pada suhu $37 \circ^{\circ} \mathrm{C}$. Menambahkan RPMI sebanyak $1 \mathrm{ml}$ pada setiap well dan diinkubasi selama 30 menit pada suhu $37^{\circ} \mathrm{C}$. Melakukan pencucian isolat menggunakan RPMI hingga tidak ada kontaminasi sel, dan sel siap diberi perlakuan.

Eksotoksin S. mutans.dipreparasi dari suspensi $S$. mutans. Pembuatan suspensi $S$. mutans: sebanyak $4 \mathrm{ml}$ BHIB dimasukkan ke dalam tabung reaksi, kemudian ditambahkan 1 ose isolat $S$. mutans kemudian dicampurkan dan diinkubasi pada suhu $37{ }^{\circ} \mathrm{C}$ selama $1 \times 24$ jam. Penentuan konsentrasi bakteri dengan densicheck sebesar 1 mcfarland. Eksotoksin bakteri diambil melalui tahapan penyaringan menggunakan syiringe filter $0.2 \mu \mathrm{m}$. Hasil penyaringan mendapatkan supernatant yang mengandung eksotoksin S. mutans.

Masing-masing bubuk kopi (spray drying dan bubuk biasa) ditimbang sebanyak $3 \mathrm{gr}$ dan dilarutkan pada air mendidih sebanyak $200 \mathrm{ml}$. Seduhan diletakkan diatas hotplate stirrer pada suhu $90^{\circ} \mathrm{C}$ dengan kecepatan 60rpm selama 1 menit kemudian didiamkan hingga mencapai suhu ruangan. Seduhan tersebut disaring menggunakan syringe filter $0.2 \mu \mathrm{m}$.

Isolat monosit pada plastic well plate diberikan perlakuan kopi sesuai dengan kelompoknya masing masing. Pada kelompok kontrol tidak diberi kopi, tetapi diberi plasebo (media RPMl sebanyak $100 \mu \mathrm{l}$ ), kelompok KS. Dipapar seduhan kopi spray dryed sebanyak $100 \mu$ dan kelompok KB, dipapar seduhan bubuk kopi biasa sebanyak $100 \mu$ l. Well plate diletakkan pada inkubator shaker selama 1,5 jam dan dilanjutkan pemaparan antigen $S$. mutans sebanyak $100 \mu \mathrm{ll}$ pada seluruh kelompok. Well plate diletakkan kembali pada inkubator shaker selama 1,5 jam pada suhu $37^{\circ} \mathrm{C}$.

Proses perlakuan selesai dilakukan, kemudian dilakukan pewarnaan menggunakan trypan blue sebanyak $50 \mu$ dan dilakukan pengamatan serta pemotretan menggunakan mikroskop inverted. ${ }^{13}$ Monosit yang viable memiliki membran yang utuh sehingga tidak menyerap warna biru (sel tampak bening), sedangkan monosit yang tidak viable membrannya rusak sehingga menyerap warna biru (sel berwarna biru). Sel yang bening dihitung sebagai sel yang viable, sedangkan sel yang menyerap warna biru dihitung sebagai sel non-viable. Parameter yang digunakan dalam penelitian ini adalah menghitung persentase monosit yang viable dengan jumlah seluruh sel monosit pada 4 
lapang pandang untuk setiap well oleh tiga orang pengamat. Dapat diperoleh dengan rumus: 6

Viabilitas sel $(\%)=$ Jumlah monosit viabel $\times 100$ Jumlah monosit seluruhnya

Hasil data perhitungan viabilitas monosit yang telah didapatkan dilanjutkan uji analisis statistik. Data dianalisis dengan menggunakan uji parametri One-Way Anova dan uji lajutan Least Significant Difference (LSD).

\section{HASIL PENELITIAN}

Hasil analisis data menunjukkan bahwa monosit yang diinkubasi dengan seduhan kopi spray dryed memiliki viabilitas yang paling tinggi dari seluruh kelompok yaitu sebesar $96,95 \%$. Kelompok yang diinkubasi dengan seduhan kopi bubuk biasa memiliki viabilitas sebesar $95,43 \%$ dan kelompok yang tidak diinkubasi dengan seduhan kopi (kontrol) memiliki viabilitas paling rendah yaitu $94,27 \%$ (Tabel 1).

Tabel 1. Efek seduhan bubuk kopi terhadap viabilitas monosit (\%)

\begin{tabular}{|c|c|}
\hline Kelompok & $\begin{array}{c}\% \text { Viabilitas } \\
\text { Monosit }\end{array}$ \\
\hline Kontrol (Mon + S) & $94,27 \pm 0,48$ \\
\hline $\begin{array}{l}\text { KS (Kopi Spray Dryed } \\
+ \text { Mon+S) }\end{array}$ & $96,95 \pm 0,39 *$ \\
\hline $\begin{array}{l}\text { KB (Kopi Bubuk Biasa } \\
+ \text { Mon+S) }\end{array}$ & $95,43 \pm 2,79$ \\
\hline $\begin{array}{l}\text { Data yang dtampilakn } \\
\text { simpangan baku } \\
\text { Mon = Monosit, } S=\text { Eksotoksin } \\
{ }^{*} \text { beda signifikan }(p<0,05) d\end{array}$ & $\begin{array}{l}\text { kan rata-rata dan } \\
\text { lompok kontrol }\end{array}$ \\
\hline
\end{tabular}

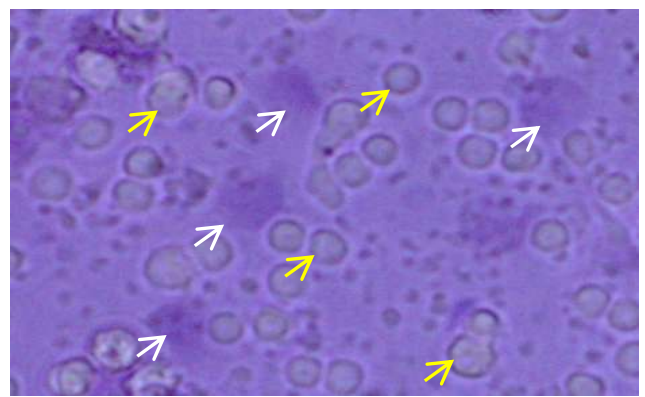

Gambar 1. Efek seduhan kopi robusta terhadap viabilitas monosit yang dipapar $S$. mutans. Sel yang viable terlihat bening dan tidak menyerap warna trypan blue (panah kuning), Sel non-viable terlihat berwarna biru karena menyerap warna trypan blue (panah putih).

Diskripsi viabilitas monosit ditunjukkan dari gambaran mikroskopis yang disajikan pada gambar 1. Sel yang viable terlihat bening dan tidak menyerap warna trypan blue, Sel nonviable terlihat benwarna biru karena menyerap warna trypan blue.

\section{PEMBAHASAN}

Hasil penelitian menunjukkan kelompok yang memiliki viabilitas terendah adalah kelompok kontrol yang dilakukan pemaparan S. mutans. Hal ini menunjukkan bahwa $S$. mutans yang dipaparkan pada monosit dapat meyebabkan penurunan viabilitas sel. Pemaparan S. mutans menstimuli respon monosit melakukan respiratory burst yang akan menghasilkan radikal bebas (ROS). Salah satu ROS yang terbentuk adalah hydroxyl radical $(\cdot \mathrm{OH})$ yang sangat reaktif dan dapat menyebabkan terjadinya peroksidasi lipid. ${ }^{2}$ Peroksidasi lipid terjadi dalam tiga fase yaitu inisiasi (pembentukan), propagasi (pemanjangan) dan terminasi. Pada tahap inisiasi $\cdot \mathrm{OH}$ yang terbentuk akan menarik elektron dari polyunsaturated faty acid (PUFA) yang merupakan komponen penting fosfolipid yang sangat rentan terhadap paparan radikal bebas karena memiliki ikatan rangkap pada rantai samping. ${ }^{14}$ Peroksidasi lipid akan berdampak secara langsung terhadap fluiditas, struktur dan fungsi membran sel yang dapat mengakibatkan menurunnya viabilitas sel.., 5

Kelompok kopi spray dryed memiliki nilai viabilitas lebih tinggi daripada kelompok kontrol dan hasil analisis data menunjukkan perbedaan yang signifikan. Perbedaan ini menunjukkan bahwa seduhan kopi robusta spray dryed mampu meningkatkan viabilitas monosit. Hal ini dapat disebabkan karena kopi memiliki kandungan antioksidan yang dapat meredam produksi radikal bebas dan stres oksidatif dapat terhenti. ${ }^{15}$

Senyawa antioksidan yang terkandung dalam kopi mampu menginduksi antioksidan endogen sebagai antioksidan primer yaitu superoxide dismutase (SOD), catalase (CAT), dan glutathione peroxidase (GPx) sehingga aktivitas antioksidan dalam tubuh meningkat. 16,17 SOD akan merubah radikal superoksida $\left(\mathrm{O}_{2}{ }^{-}\right)$yang dihasilkan menjadi hidrogen peroksida $\left(\mathrm{H}_{2} \mathrm{O}_{2}\right) . \mathrm{H}_{2} \mathrm{O}_{2}$ yang terbentuk dirubah oleh enzim CAT menjadi $\mathrm{H}_{2} \mathrm{O}$ dan $\mathrm{O}_{2}$ serta oleh GPx menjadi $\mathrm{H}_{2} \mathrm{O}$ dengan mengoksidasi gluthatione (GSH) hingga terbentuk gluthatione disulfide (GSSG)..$^{17}$

Antioksidan bersifat sangat mudah dioksidasi, sehingga radikal bebas akan mengoksidasi antioksidan dan melindungi molekul lain dari kerusakan akibat oksidasi oleh radikal bebas atau oksigen reaktif. Antioksidan kopi juga berperan sebagai antioksidan sekunder dengan melakukan sistem pertahanan memotong reaksi oksidasi berantai dari radikal bebas atau menarik radikal bebas sehingga radikal bebas tidak bereaksi dengan komponen seluler. ${ }^{17}$ Ditahap inisiasi, diduga antioksidan akan berikatan dengan radikal bebas sehingga radikal bebas tidak mengikat rantai asam lemak tak jenuh pada membran sel, sehingga tahap propagasi dapat terhambat.

Dari hasil penelitian menunjukkan bahwa kelompok monosit yang diinkubasi seduhan kopi robusta secara spray dryed memiliki viabilitas lebih tinggi dibandingkan seduhan kopi bubuk biasa. Hal ini terjadi karena proses pengolahan kopi dapat berpengaruh 
terhadap ketersediaan antioksidan." Proses pengolahan spray dryed merupakan tahapan pengeringan dalam pembuatan kopi instan yang akan menyebabkan bubuk kopi dalam seduhan akan terlarut dan tidak menyisakan ampas. Semakin banyak kopi yang terlarut dalam air maka makin banyak pula senyawa antioksidan yang terlarut.18,19 Pengolahan kopi robusta secara spray dryed mampu meningkatkan kandungan polifenolnya, sehingga antioksidan yang terkandung lebih tinggi.20 Kandungan antioksidan yang lebih tinggi pada kopi spray dryed diduga dapat meningkatkan viabilitas monosit lebih baik daripada seduhan kopi bubuk biasa.

Hasil uji LSD antara kelompok yang diinkubasi dengan seduhan kopi spray dryed dengan kelompok yang diinkubasi seduhan kopi bubuk biasa memiliki perbedaan yang tidak signifikan. Hal ini diduga karena kecilnya konsentrasi seduhan kopi pada saat perlakuan dalam penelitian, sehingga kadar antioksidan yang terkandung pada seduhan kopi robusta masih kurang kuat untuk melihat perbedaan antara kedua jenis pengolahan kopi.

Kelompok kopi bubuk biasa memiliki viabilitas lebih tinggi daripada kelompok kontrol, namun hasil uji LSD menunjukkan tidak adanya perbedaan yang signifikan. Hal ini diduga disebabkan karena seduhan kopi bubuk biasa memiliki ampas yang masih memiliki kandungan antioksidan. Ampas yang tidak larut mengakibatkan kurangnya kandungan antioksidan untuk meningkatkan persentase viabilitas monosit, sehingga tidak didapatkan perbedaan yang bermakna antara kelompok kopi bubuk biasa dengan kelompok kontrol.

Kesimpulan penelitian ini adalah Seduhan kopi robusta (Coffea canephora) yang diproses secara spray dryed terbukti dapat meningkatkan viabilitas monosit yang dipapar eksotoksin S. mutans in vitro. Perlu penelitian lebih lajut terkait efek konsentrasi dan durasi inkubasi seduhan kopi, juga efek berbagai jenis olahan bubuk kopi

\section{DAFTAR PUSTAKA}

1. Baratawidjaja, K. G., dan I. Rengganis. Imunologi Dasar. Edisi ke-12. Jakarta: Balai Penerbit FKUI. 2018.

2. Birben, E., Sahiner, U. M., Sackesen, C., Erzurum, S., dan Kalayci, O. Oxidative stress and antioxidant defense. World Allergy Organization Journal. 2012. 5:270.

3. John, Greer P., R. George, G. Bertil, A. Daniel A., M. Jr. Robert T., L. Alan F., A. Frederick R., D. Angela, F. Todd A. Wintrobe's Clinical Hematology Ed 14. Philadelphia. Wolters Kluwer. 2018.

4. Sayuti, Kesuma dan R. Yenrina. Antioksidan Alami dan Sintetik Cetakan I. Padang: Andalas University Press. 2015.
5. Yuslianti, Euis Reni. Pengantar Radikal Bebas dan Antioksidan. Jogjakarta: Deepublish. 2018.

6. Lovis, K.S. dan A. C. Siegel. Cell viability analysis using trypan blue: manual and automated methods. Methods Mol Biol. 2011 . 740:7-12.

7. Dorland, W. A. N. Kamus Saku Kedokteran Dorland Edisi 30. Jakarta: Elsevier. 2015.

8. Yashin, A., Y. Yashin, J. Y. Wang, dan B. Nemzer. Antioxidant and antiradical activity of coffee. Antioksidan. 2013. 2(4): 230-245.

9. Farah, A. Coffee: Emerging Health Effect And Dissease Prevention. Oxford: WileyBlackwell. 2012.

10. Dewanti, I. D. A. R. Peningkatan Ekspresi GSH (Gluthathione) pada Monosit yang Dipapar Biji Kopi dan DMBA (7,12dimethylbenz(a)anthrancene).

Stomatognatic - Jurnal Kedokteran Gigi, [S.I.], v. 13, n. 1, p. 12-16, mar. 2017. ISSN 2442-4935

11. Yusmarini. Mini review senyawa polifenol pada kopi pengaruh pengolahan, metabolisme dan hubungannya dengan kesehatan. SAGU. 2011.10 (2) : 22-30.

12. Niseteo, T. D. K., A. Belšč 'ak-Cvitanovic' dan D. H. Maja B. Bioactive composition and antioxidant potential of different commonly consumed coffee brews affected by their preparation technique and milk addition. Journal of Sci Verse Science Direct Food Chemistry. 2012. 134: 1870-1877.

13. Budiraharjo, Roedy. Peningkatan Viabilitas Monosit oleh Biji Kopi Robusta terhadap Streptococcus Mutans. 2016. http://repository.unej.ac.id/handle/12345 6789/73665 [Diakses pada 17 Mei 2018]

14. Gaschler, M. M. dan B. R. Stockwell. Lipid peroxidation in cell death. Biochemical and Biophysical Research Communications: 2017. 482.

15. Susilawati, I.D.A, A. Safaatin dan J. Burlakovs. Coffee reduced the production of neutrophil superoxide radical in vitro. The 2nd International Conference on Natural Resources and Life Sciences (NRLS). 2019.

16. Herawati, H., dan Sukohar A. Pengaruh Chlorogenic acid Kopi Robusta Lampung terhadap Ekskresi Cyclin DI dan Caspase 3 pada Cell Lines HEP-G2. Seminar Nasional Sains \& Teknologi $\vee$ Lembaga Penelitian Universitas Lampung. 2013. 
17. Werdhasari, Asri. Peran Antioksidan Bagi Kesehatan. Jurnal Biotek Medisiana Indonesia. 2014.3 (2); 59-68.

18. Pratiwi, I.D.P. Kartika. Modul MK. Teknologi Kopi. Fakultas Teknologi Pertanian. Universitas Udayana. 2017.
19. Mulanto, S. dan E. Suharyanto. Kopi, Seduhan, dan Kesehatan. Jember; Puslitkoka Indonesia. 2012.

20. Ghirisan, A. dan Vasile M. Comparative Study of Spray Dryed and Freeze Dryed on the Soluble Coffee Properties. Studia UBB Chemia LXII. 2017. (4): Tom II 309-316. 